\title{
Internal Branding in the Gig and Sharing Economy: Enhancing Service Providers' Engagement to Achieve Higher Customer Satisfaction
}

\author{
Obed Niyomwungeri \\ Jacobs University Bremen, Germany \\ oniyomwungeri@jacobs-alumni.de
}

\begin{abstract}
Traditional service industries rely on internal branding and employee engagement to ensure their employees deliver their brand promises. However, they are evolving into more on-demand work than ever before. Both gig and sharing economy (GE\&SE) platforms enable individuals to provide on-demand services. Although those service providers (SPS) are not employed by GE\&SE platforms, consistent delivery of brand promises by the SPs is crucial in GE\&SE too. Thus, we aim to investigate the importance of internal branding in GE\&SE as a key factor in achieving higher customer satisfaction by analyzing the SP's engagement to the brand. Accordingly, we develop a comparison framework and conduct nine interviews with SPs, which we then analyze by means of a cross-case analysis. The results show that internal branding practices can play an important role in enhancing the SPs' engagement levels. Moreover, highly engaged SPs will go the extra mile to satisfy the customers' needs.
\end{abstract}

\section{Introduction}

The sharing economy (SE), also known as collaborative consumption, is described 'as a peer-topeer marketplace that allows the exchange of unused resources, goods, and services between individuals'. [1]; Airbnb, BlablaCar, Spacer, and Kickstarter are examples of SE platforms. The gig economy (GE) is defined as "a labor market of ad hoc, short-term, freelance, or otherwise non-permanent jobs" [2]. It can include the use of personal physical assets such as cars when providing rides on Uber or making deliveries on Amazon Flex, as well as the tasks, which might be only limited to a knowledge or skills base; in this case, workers are professional freelancers on platforms like Upwork, Toptal, or taskers on TaskRabbit [3].

Although there is a distinction between these two concepts, both the gig and sharing economy (GE\&SE) rely on high technology to create and manage platform-based labor markets (PBLM) [4]. Moreover, another common characteristic is that work in these PBLM is not defined by the traditional employeremployee relation, but instead on a project-specific

\author{
Stanislav Chankov \\ Jacobs University Bremen, Germany \\ s.chankov@jacobs-university.de
}

basis. Hence, workers are regarded as independent contractors rather than fulltime employees [5].

It is argued that consistent delivery of brand promises is a requisite for firms operating in both GE\&SE to prosper [6], since these firms "do not create the brand value directly and, consequently, do not control their value proposition" [7].

In traditional service industries such as hospitality and tourism, the increasing concern about the role of employees in building brand equity has led to the emergence of internal branding strategies. Internal branding seeks to ensure that employees enact and deliver the promised brand values, which determine customers' expectations [8], by enhancing the knowledge of employees about the brand's promise, personality, and values [9]. In the GE\&SE, however, service providers (SP), such as Uber drivers or Airbnb hosts, are not considered to be employees of the corresponding platform, but rather as independent contractors [5]. While current internal branding literature has focused on traditional employee studies, there is a lack of literature on independent contractors operating in PBLM. Yet, as SPs interact with customers similarly to employees in the traditional service industries, it can be inferred that GE\&SE firms' strategic communication of brand values to SPs is essential in order to harness their full engagement.

The implications of internal branding in the SE were studied by surveying more than 100 service providers on SE platforms [7]. It was established that internal branding practices have the potential to positively influence employee-based brand equity (EBBE) benefits such as brand commitment, brand involvement, and brand citizenship behavior. Besides, [7] suggests that higher EBBE benefits lead to increased customer satisfaction. However, [7] only examines internal branding in SE but does not address internal branding in GE. Further, a sustainable success of a company depends on a much broader concept that also encompasses other constructs such as brand commitment, brand involvement, and brand citizenship behavior - employee engagement.

Although the concept of employee engagement has been well-studied in the context of traditional employment arrangements, little concern has been drawn to the concept in the context of PBLM [10]. As 


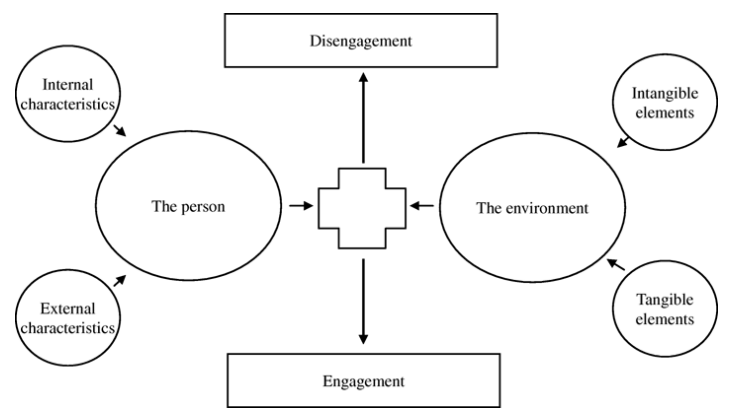

Figure 1: Emerging model of engagement and disengagement

the future of work appears to lean towards gig work and the supply of goods will involve more sharing than owning assets [11], it is crucial for firms operating in these market arrangements to understand the motives driving service providers and what factors trigger their engagement. Existing research on the GE\&SE has focused on the welfare of service providers in terms of employment laws, and mainly assessing the managerial point of view [2], however, the service providers' point of view has rarely been addressed.

Thus, the purpose of this paper is to investigate the importance of internal branding in the gig and sharing economy as a key factor in achieving higher customer satisfaction by analyzing the SP's engagement to the brand. Accordingly, we develop a comparison framework and conduct nine interviews with SPs from different GE\&SE platforms, which we then analyze by means of a cross-case analysis.

\section{Methodology}

\subsection{Comparison framework}

The comparison framework was derived from the emerging model of engagement and disengagement [12], which suggests that interactions between the person and the environment can result in either employee engagement or employee disengagement (see Figure 1). It was originally applied in the context of traditional employment arrangements. The 'person' depicts personal traits such as emotions, personality, physical traits; the 'environment' represents the totality of elements in the environment such as people, climate, physical space, culture. Tangible elements of the environment include relationship with co-workers, interactions with supervisors, and organizational procedures. Intangible elements on the other hand include trust, cooperation, being free from fear, a sense of community, and attachment and learning.

[12] defined internal characteristics of the person as "items that affect the person and are inside of the person such as feelings and emotions"; they include verbal illustrations of perceptive or affectual characteristics such as trust, motivation, confidence, desire to learn, feeling valued, ownership and the aspiration of challenge. External characteristics "items that affect the person but manifested outside the person and visible to others", however, include the person's health or their family [12].

This model aligns with the findings of [13], which suggested that employee engagement is a dynamic and volatile concept that requires consistent positive interactions between employees and managers. Thus, it can be inferred that the overall organizational environment positively influences the engagement of employees. As suggested in the EBBE model by [14], internal branding practices play a vital role in enhancing the employees' perception of their organization as it helps them to understand and identify with brand values of their organization. Combining the models of [14] and [12] and applying them to GE\&SE, we suggest that internal branding practices can enhance the SP engagement levels. Thus, highly engaged SPs will provide better services, which in return increases customer satisfaction.

Our comparison framework considers two main themes, internal branding and service provider engagement, while also analyzing their impact on customer satisfaction. Accordingly, constructs for the three framework themes were developed. The constructs that define internal branding and the consequences of SP engagement were derived from studies presented by [7] - the EBBE model by [14] applied to SE, and [15] respectively. As the use of rating systems is common in GE\&SE [7], ratings and overall customer satisfaction from the SP perspective were used as constructs for customer satisfaction.

In terms of internal branding, brand-related information is communicated from the organization to the employees. It is important that employees learn and understand brand-related information and play a role in generating constructive feedback based on which an organization can improve its internal processes. As presented in the EBBE model, information generation is the extent to which employees believe that their feedback to the organization is considered when implementing new strategies. As a result, knowledge dissemination is the extent to which employees perceive that the organization communicates brand knowledge in a relevant manner. Yet, this can only be achieved in a conducive environment allowing free communication between the organization and employees; hence defining openness as a construct for internal branding. Further, role clarity expressing the clarity level of employees towards their roles, and management support defined as the extent to which employees 
Table 1. Profile of selected platforms and service providers (SPs)

\begin{tabular}{|c|c|c|c|c|c|c|c|c|c|}
\hline \multirow{2}{*}{$\begin{array}{l}\text { Sector } \\
S P\end{array}$} & \multicolumn{2}{|c|}{ Hospitality } & \multicolumn{2}{|c|}{ Packages Delivery (PD) } & \multicolumn{3}{|c|}{ Fresh Food Delivery (FFD) } & \multicolumn{2}{|c|}{ Carpooling } \\
\hline & Case 1 & Case 2 & Case 3 & Case 4 & Case 5 & Case 6 & Case 7 & Case 8 & Case 9 \\
\hline Duration & 8 years & 6 years & 2 months & 3 months & 8 months & 16 months & 3 months & 3 months & 6 months \\
\hline SP work region & India & Poland & US & Germany & Germany & Germany & Germany & Germany & Germany \\
\hline Main occupation & No & No & No & No & No & No & Yes & No & No \\
\hline Platform & \multicolumn{2}{|c|}{ A } & B & $\mathrm{C}$ & $\mathrm{D}$ & \multicolumn{2}{|c|}{$\mathrm{E}$} & \multicolumn{2}{|c|}{$\mathrm{F}$} \\
\hline Founded & \multicolumn{2}{|c|}{$>10$ years } & $>5$ years & $>5$ years & $>5$ years & \multicolumn{2}{|c|}{$>10$ years } & \multicolumn{2}{|c|}{$>10$ years } \\
\hline Labor market & \multicolumn{2}{|c|}{ SE } & GE & GE & GE & \multicolumn{2}{|c|}{ GE } & \multicolumn{2}{|c|}{ SE } \\
\hline $\begin{array}{l}\text { Platform's } \\
\text { locations }\end{array}$ & \multicolumn{2}{|c|}{ Worldwide } & Worldwide & $\begin{array}{c}\text { North } \\
\text { America }\end{array}$ & $\begin{array}{l}\text { Europe, Asia \& } \\
\text { North America }\end{array}$ & \multicolumn{2}{|c|}{ Europe } & \multicolumn{2}{|c|}{$\begin{array}{l}\text { Europe, Asia \& } \\
\text { South America }\end{array}$} \\
\hline
\end{tabular}

perceive that the organization acknowledges their efforts, are considered as further constructs [7], [14].

Regarding SP engagement, the consequences of engagement such as organizational commitment which defines employees' psychological attachment or feeling of belonging towards an organization, and the organizational trust as a measure of employees' trust in the organization's consistency in delivering promises made to employees were evaluated. Organizational citizenship behavior (OCB) is defined as the brand consistent behaviors exhibited by employees that are "above and beyond the norm". These behaviors can be directed towards the organization or the individual. In the former case, employees express discretionary efforts to uphold the organization's success; in the latter, employees tend to dedicate spare time to help co-workers who face difficulties. Job satisfaction is investigated in terms of psychological meaningfulness, safety, and availability of the employee according to [13]. Further, personal development is considered as a measure of how employees feel challenged when performing their activities. [16] describe the desire for a challenge as one of the unique personalities an employee can possess. The last constructs considered for gauging the consequences of employee engagement can be seen in terms of the employee's intentions to stay with the organizations and their exhibition of positive word-ofmouth (WOM); which is seen as the extent to which employees speak positively of the organization and would recommend it to others [14]-[16].

Since employees in the PBLM act as independent contractors [7], in this paper the terms "service providers (SP)" and "platform" are used as equivalents of "employees" and the "organization" they work for.

\subsection{Interview design and cross-case analysis}

To explore SP engagement levels from the SPs' side, we chose the semi-structured interview format as it allows room for an open discussion and follow-up questions to clarify answers and explore spontaneous points of interest [17]. An interview questionnaire was used as a guide to help keep the focus on the research topic while allowing for openness and flexibility [18]. 22 questions were developed based on the comparison framework, covering the constructs of the two main themes, internal branding and SP engagement, coupled with customer satisfaction. External scholars reviewed the wording of the questions to ensure that they are clear and free of bias. Further, given the limited information about the concept of engagement and internal branding in the existing literature of PBLM, a cross-case analysis was chosen as it can provide a better overall understanding of the studied subjects by comparing their similarities and differences [19].

To ensure that the collected data is diverse and provides a holistic representation [19] of the GE\&SE, platforms operating in different sectors, and covering a diversified market were selected. Social media posts asking for interview volunteers were made. Thus, nine SPs representing six GE\&SE platforms operating in four different areas were recruited. The interviews were conducted via video calls and lasted about 40 minutes. Table 1 shows the summarized profiles of the chosen platforms and interviewed service providers.

\section{Results}

\subsection{Internal branding}

Table 2 shows the results for internal branding. When it comes to Openness, the main aim was to find out if there are communication channels through which SPs communicate with the platform reps when they have any concerns. It can be noticed that in most cases phone calls are used as the prime communication channel, followed by emails and communication through mobile apps. Besides, Case 4 stated that their platform requires SPs to fill in weekly surveys about their experience. For Cases 6 and 7, the platform goes a step further and connects SPs via WhatsApp groups in order to facilitate smooth and quick communication. Cases 8 and 9 from the carpooling sector, however, were uncertain if such communication channels exist. Case 8 said that there is a way to report incidences to the platform reps, but also says, "if you really want to contact someone from their side, I think you would 
Table 2. Results for Internal Branding

\begin{tabular}{|c|c|c|c|c|c|}
\hline & Openness & $\begin{array}{c}\text { Information } \\
\text { generation }\end{array}$ & $\begin{array}{c}\text { Knowledge } \\
\text { dissemination }\end{array}$ & $\begin{array}{l}\text { Role } \\
\text { clarity }\end{array}$ & $\begin{array}{c}\text { Management } \\
\text { support }\end{array}$ \\
\hline Case 1 & $\begin{array}{l}\text { Email, phone } \\
\text { call }\end{array}$ & Uncertain & $\begin{array}{l}\text { - There are meetings but not in every city. } \\
\text { - Generic emails about how things can be } \\
\text { done better are sent. }\end{array}$ & $\begin{array}{l}\text { - Roles are clear. } \\
\text { - I don't feel like a } \\
\text { brand representative }\end{array}$ & $\begin{array}{l}\text { - They are usually } \\
\text { prompt in listening. } \\
\text { - The reward systems } \\
\text { can be improved. }\end{array}$ \\
\hline Case 2 & $\begin{array}{l}\text { Email, phone } \\
\text { call }\end{array}$ & $\begin{array}{l}\text { Feedback is } \\
\text { considered. }\end{array}$ & $\begin{array}{l}\text { - There are meetings but not in every city. } \\
\text { - Generic emails about how things can be } \\
\text { done better are sent. }\end{array}$ & $\begin{array}{l}\text { - Roles are clear. } \\
\text { - I don't feel like a } \\
\text { brand representative }\end{array}$ & $\begin{array}{l}\text { - They are very } \\
\text { helpful. } \\
\text { - The reward systems } \\
\text { can be improved. }\end{array}$ \\
\hline Case 3 & $\begin{array}{l}\text { Mobile App, } \\
\text { phone call }\end{array}$ & $\begin{array}{l}\text { Feedback is } \\
\text { considered. }\end{array}$ & $\begin{array}{l}\text { - Through an online orientation seminar. } \\
\text { But not extensively. } \\
\text { - We are only informed of what we } \\
\text { should do but not why. }\end{array}$ & $\begin{array}{l}\text { - Roles are clear. } \\
\text { - I don't feel like a } \\
\text { brand representative }\end{array}$ & They are not helpful. \\
\hline Case 4 & $\begin{array}{l}\text { Email, phone } \\
\text { calls, live } \\
\text { chats, weekly } \\
\text { surveys }\end{array}$ & Uncertain & $\begin{array}{l}\text { - Through an online orientation seminar. } \\
\text { But not extensively. } \\
\text { - We are only informed of what we } \\
\text { should do but not why. }\end{array}$ & $\begin{array}{l}\text { - Roles are clear. } \\
\text { - I don't feel like a } \\
\text { brand representative }\end{array}$ & $\begin{array}{l}\text { - They are not } \\
\text { helpful. } \\
\text { - There are reward } \\
\text { systems. }\end{array}$ \\
\hline Case 5 & $\begin{array}{l}\text { Mobile App, } \\
\text { phone call }\end{array}$ & $\begin{array}{l}\text { Feedback is } \\
\text { considered. }\end{array}$ & $\begin{array}{l}\text { - Through an in-person orientation } \\
\text { seminar. } \\
\text { - We are only informed of what we } \\
\text { should do but not why. } \\
\text { - They remind us of the brand promises } \\
\text { whenever they see a violation. }\end{array}$ & $\begin{array}{l}\text { - Roles are clear. } \\
\text { - I feel like a brand } \\
\text { representative. }\end{array}$ & $\begin{array}{l}\text { - They are helpful. } \\
\text { - There are reward } \\
\text { systems. }\end{array}$ \\
\hline Case 6 & $\begin{array}{l}\text { Mobile App, } \\
\text { Phone calls, } \\
\text { and WhatsApp } \\
\text { groups }\end{array}$ & $\begin{array}{l}\text { Feedback is } \\
\text { considered. }\end{array}$ & $\begin{array}{l}\text { - Through an in-person orientation } \\
\text { seminar. } \\
\text { - We are only informed of what we } \\
\text { should do but not why. } \\
\text { - They remind us of the brand promises } \\
\text { whenever they see a violation. }\end{array}$ & $\begin{array}{l}\text { - Roles are clear. } \\
\text { - I feel like a brand } \\
\text { representative. }\end{array}$ & $\begin{array}{l}\text { - They are very } \\
\text { helpful. } \\
\text { - There are reward } \\
\text { systems. }\end{array}$ \\
\hline Case 7 & $\begin{array}{l}\text { Mobile App, } \\
\text { phone calls, } \\
\text { and WhatsApp } \\
\text { groups }\end{array}$ & Uncertain & $\begin{array}{l}\text { - Through an in-person orientation } \\
\text { seminar. } \\
\text { - We are informed of what we should do } \\
\text { and why we should do so. } \\
\text { - They remind us of the brand promises } \\
\text { whenever they see a violation. }\end{array}$ & $\begin{array}{l}\text { - Roles are clear. } \\
\text { - I feel like a brand } \\
\text { representative. }\end{array}$ & $\begin{array}{l}\text { - They are very } \\
\text { helpful. } \\
\text { - There are reward } \\
\text { systems. }\end{array}$ \\
\hline Case 8 & Uncertain & $\begin{array}{l}\text { I think } \\
\text { feedback is } \\
\text { considered. }\end{array}$ & $\begin{array}{l}\text { They send emails about generic } \\
\text { information but not emphasizing brand } \\
\text { promises. }\end{array}$ & $\begin{array}{l}\text { - Guidelines are clear. } \\
\text { I don't feel like a } \\
\text { brand representative. }\end{array}$ & $\begin{array}{l}\text { - Uncertain. } \\
\text { - There are reward } \\
\text { systems. }\end{array}$ \\
\hline Case 9 & Uncertain & Uncertain & $\begin{array}{l}\text { They send emails about generic } \\
\text { information but not emphasizing brand } \\
\text { promises. }\end{array}$ & $\begin{array}{l}\text { - Guidelines are clear. } \\
\text { - I don't feel like a } \\
\text { brand representative. }\end{array}$ & $\begin{array}{l}\text { - Uncertain. } \\
\text { - There are reward } \\
\text { systems. }\end{array}$ \\
\hline
\end{tabular}

have to go through the website (...) however, I am unaware of any other sort of communication".

In terms of information generation, 5 out of the 9 SPs believed the feedback they provide to the platform reps is received and considered when developing strategies that facilitate SP activities on the platform. The remaining 4 SPs, however, were uncertain as to whether SP feedback is considered, or if platform reps actively seek SP feedback, to begin with. For instance, Cases 4,7 , and 8 reported that they had not been asked to provide feedback before.

As shown on Table 2, SPs from the PD (Cases 3-4) and FFD (Cases 5-7) areas gain brand knowledge through orientation seminars; the seminars are online for the PD SPs whereas in the FFD in-person seminars are conducted. SPs operating in the hospitality (Cases 1-2) and carpooling (Cases 8-9) areas on the other hand indicated that they receive generic emails from platform representatives; however, these emails do not seem to emphasize brand knowledge. To understand further if SPs were informed about the brand promises to adhere to when providing services, they were asked if platform reps communicate to SPs the motives behind the rules and guidelines defining the activities 
Table 3. Results for Service Provider Engagement

\begin{tabular}{|c|c|c|c|c|c|c|c|}
\hline & $\begin{array}{l}\text { Organizational } \\
\text { commitment }\end{array}$ & $\begin{array}{l}\text { Organizational } \\
\text { citizenship behavior }\end{array}$ & $\begin{array}{l}\text { Organizational } \\
\text { trust }\end{array}$ & Job Satisfaction & $\begin{array}{l}\text { Personal } \\
\text { development }\end{array}$ & $\begin{array}{l}\text { Intention } \\
\text { to stay }\end{array}$ & $\begin{array}{l}\text { Word of } \\
\text { mouth }\end{array}$ \\
\hline Case 1 & $\begin{array}{l}\text { - I share some } \\
\text { values with the } \\
\text { platform. } \\
\text { - Indifferent }\end{array}$ & $\begin{array}{l}\text { - I would willingly } \\
\text { help guests in all } \\
\text { possible ways. } \\
\text { - Not often since I } \\
\text { am not that active. } \\
\text { But I would like to. }\end{array}$ & $\begin{array}{l}\text { I do not expect } \\
\text { much from } \\
\text { them. }\end{array}$ & $\begin{array}{l}\text { - I find my services } \\
\text { meaningful. } \\
\text { - I feel autonomous in my } \\
\text { activities. } \\
\text { - I feel personally well } \\
\text { equipped. }\end{array}$ & $\begin{array}{l}\text { It is as good } \\
\text { as going to a } \\
\text { hotel } \\
\text { management } \\
\text { school. }\end{array}$ & $\begin{array}{l}\text { I intend } \\
\text { to stay for } \\
\text { longer. }\end{array}$ & $\begin{array}{l}\text { Highly } \\
\text { recommend } \\
\text { it. }\end{array}$ \\
\hline Case 2 & $\begin{array}{l}\text { - I share some } \\
\text { values with the } \\
\text { platform. } \\
\text { - Their } \\
\text { problems are } \\
\text { my problems. }\end{array}$ & $\begin{array}{l}\text { - I can say that I am } \\
\text { a concierge. } \\
\text { - I engage with } \\
\text { fellow SPs but not } \\
\text { through the } \\
\text { platform. }\end{array}$ & $\begin{array}{l}\text { They consider } \\
\text { our interests. }\end{array}$ & $\begin{array}{l}\text { - I find my services very } \\
\text { meaningful. } \\
\text { - I feel autonomous in my } \\
\text { activities. } \\
\text { - I feel personally well } \\
\text { equipped. }\end{array}$ & $\begin{array}{l}\text { There is } \\
\text { potential for } \\
\text { personal } \\
\text { development. }\end{array}$ & $\begin{array}{l}\text { I intend } \\
\text { to stay for } \\
\text { longer. }\end{array}$ & $\begin{array}{l}\text { Highly } \\
\text { recommend } \\
\text { it. }\end{array}$ \\
\hline Case 3 & $\begin{array}{l}\text { - Uncertain } \\
\text { - Indifferent }\end{array}$ & $\begin{array}{l}\text { - I try all possible } \\
\text { means to find the } \\
\text { customer. } \\
\text { - We mostly have } \\
\text { no time to interact } \\
\text { since all rush to } \\
\text { finish their } \\
\text { deliveries. }\end{array}$ & $\begin{array}{l}\text { They consider } \\
\text { our interests. }\end{array}$ & $\begin{array}{l}\text { - I find my services } \\
\text { meaningful. } \\
\text { - I feel autonomous in my } \\
\text { activities. } \\
\text { - I feel personally well } \\
\text { equipped. }\end{array}$ & $\begin{array}{l}\text { I don't see } \\
\text { the potential } \\
\text { for personal } \\
\text { development. }\end{array}$ & $\begin{array}{l}\text { I intend } \\
\text { to stay for } \\
\text { longer. }\end{array}$ & $\begin{array}{l}\text { For a side } \\
\text { job, I would } \\
\text { recommend it } \\
\text { but not full- } \\
\text { time } \\
\text { employment. }\end{array}$ \\
\hline Case 4 & $\begin{array}{l}\text { - I share some } \\
\text { values with the } \\
\text { platform. } \\
\text { - I am glad I } \\
\text { did it. }\end{array}$ & $\begin{array}{l}\text { Everyone is in it for } \\
\text { themselves. }\end{array}$ & $\begin{array}{l}\text { They consider } \\
\text { our interests. }\end{array}$ & $\begin{array}{l}\text { - I find my services } \\
\text { meaningful. } \\
\text { - I feel autonomous in my } \\
\text { activities. } \\
\text { - I feel personally well } \\
\text { equipped. }\end{array}$ & $\begin{array}{l}\text { There is } \\
\text { potential for } \\
\text { personal } \\
\text { development. }\end{array}$ & $\begin{array}{l}\text { Currently } \\
\text { looking } \\
\text { for better } \\
\text { options. }\end{array}$ & $\begin{array}{l}\text { For a side } \\
\text { job, I would } \\
\text { recommend it } \\
\text { but not full- } \\
\text { time } \\
\text { employment. }\end{array}$ \\
\hline Case 5 & $\begin{array}{l}\text { - I share some } \\
\text { values with the } \\
\text { platform. } \\
\text { - I am glad I } \\
\text { did it. }\end{array}$ & $\begin{array}{l}\text { - I always consider } \\
\text { what is best for the } \\
\text { customer. } \\
\text { - I engaged in } \\
\text { helping SPs who } \\
\text { had problems. }\end{array}$ & $\begin{array}{l}\text { They highly } \\
\text { consider our } \\
\text { interests. }\end{array}$ & $\begin{array}{l}\text { - I find my services } \\
\text { meaningful. }\end{array}$ & $\begin{array}{l}\text { There is } \\
\text { potential for } \\
\text { personal } \\
\text { development. }\end{array}$ & $\begin{array}{l}\text { Already } \\
\text { left. }\end{array}$ & $\begin{array}{l}\text { I already } \\
\text { recommended } \\
\text { others. }\end{array}$ \\
\hline Case 6 & $\begin{array}{l}\text { - I share some } \\
\text { values with the } \\
\text { platform. } \\
\text { - I am glad I } \\
\text { did it. }\end{array}$ & $\begin{array}{l}\text { - I try to stay } \\
\text { focused on the work } \\
\text { to do the best. } \\
\text { - I engaged in } \\
\text { helping SPs who } \\
\text { had problems. }\end{array}$ & $\begin{array}{l}\text { They highly } \\
\text { consider our } \\
\text { interests. }\end{array}$ & $\begin{array}{l}\text { - I find my services } \\
\text { meaningful. } \\
\text { - I feel autonomous in my } \\
\text { activities and free to voice } \\
\text { my opinion. } \\
\text { - I feel personally well } \\
\text { equipped. }\end{array}$ & $\begin{array}{l}\text { There is } \\
\text { potential for } \\
\text { personal } \\
\text { development. }\end{array}$ & $\begin{array}{l}\text { Already } \\
\text { left. }\end{array}$ & $\begin{array}{l}\text { Highly } \\
\text { recommend } \\
\text { it. }\end{array}$ \\
\hline Case 7 & $\begin{array}{l}\text { - I share some } \\
\text { values with the } \\
\text { platform. } \\
\text { - I am glad I } \\
\text { did it. }\end{array}$ & $\begin{array}{l}\text { - I try all possible } \\
\text { means to find the } \\
\text { customer. } \\
\text { - I would help other } \\
\text { SPs facing } \\
\text { difficulties. }\end{array}$ & $\begin{array}{l}\text { They highly } \\
\text { consider our } \\
\text { interests. }\end{array}$ & $\begin{array}{l}\text { - I find my services } \\
\text { meaningful. } \\
\text { - I feel autonomous in my } \\
\text { activities. } \\
\text { - I feel personally well } \\
\text { equipped. }\end{array}$ & $\begin{array}{l}\text { There is } \\
\text { potential for } \\
\text { personal } \\
\text { development. }\end{array}$ & $\begin{array}{l}\text { I intend } \\
\text { to stay for } \\
\text { longer. }\end{array}$ & $\begin{array}{l}\text { I already } \\
\text { recommended } \\
\text { others. }\end{array}$ \\
\hline Case 8 & $\begin{array}{l}\text { - I share some } \\
\text { values with the } \\
\text { platform. } \\
\text { - I am glad I } \\
\text { did it. }\end{array}$ & $\begin{array}{l}\text { - Unaware of any } \\
\text { forums linking SPs. } \\
\text { - I would be willing } \\
\text { to help other SPs } \\
\text { having difficulty. }\end{array}$ & $\begin{array}{l}\text { They highly } \\
\text { consider our } \\
\text { interests. }\end{array}$ & $\begin{array}{l}\text { - I find my services } \\
\text { meaningful. } \\
\text { - I feel autonomous in my } \\
\text { activities. } \\
\text { - I feel personally well } \\
\text { equipped. }\end{array}$ & $\begin{array}{l}\text { There is } \\
\text { potential for } \\
\text { personal } \\
\text { development. }\end{array}$ & $\begin{array}{l}\text { I intend } \\
\text { to stay for } \\
\text { longer. }\end{array}$ & $\begin{array}{l}\text { Highly } \\
\text { recommend } \\
\text { it. }\end{array}$ \\
\hline Case 9 & $\begin{array}{l}\text { - Uncertain } \\
\text { - I am glad I } \\
\text { did it. }\end{array}$ & $\begin{array}{l}\text { I haven't engaged } \\
\text { with other SPs. }\end{array}$ & $\begin{array}{l}\text { They highly } \\
\text { consider our } \\
\text { interests. }\end{array}$ & $\begin{array}{l}\text { - I find my services } \\
\text { meaningful. } \\
\text { - I feel autonomous in my } \\
\text { activities. } \\
\text { - I feel personally well } \\
\text { equipped. }\end{array}$ & $\begin{array}{l}\text { There is } \\
\text { potential for } \\
\text { personal } \\
\text { development. }\end{array}$ & $\begin{array}{l}\text { I intend } \\
\text { to stay for } \\
\text { longer. }\end{array}$ & $\begin{array}{l}\text { I already } \\
\text { recommended } \\
\text { others. }\end{array}$ \\
\hline
\end{tabular}


on the platforms. To this question, most of the participants indicated that they are informed on what to do when providing service, but they are not told why they should do so; with the exception of Case 7. It is worth noticing that SPs from the fresh food delivery area are reminded of the brand promises from time to time. Hence, they perceived themselves as brand representatives of their respective platforms, whereas the other SPs did not possess the same perception.

All SPs appeared to be well informed about their roles as they perceive the rules and guidelines defining their jobs to be clear enough. Further, they indicated that the platforms are intuitive and very easy to learn and use. Due to this fact, Cases 8 and 9 implied that one would barely need support from the platform reps. The respective SPs have, thus, not been in a situation whereby they needed assistance from the platform reps; thus, they were uncertain and could not rate the support offered by platform reps. All other SPs, except Cases 3 and 4, found the platform reps to be helpful. Lastly, all SPs implied that their platforms provide incentives for SPs through established reward systems.

\subsection{Service provider engagement}

Table 3 shows the results for SP engagement. Organizational commitment is one of the major antecedents considered hereby. Most of the SPs tended to say that they share some values with the platform they operate on, except Cases 3 and 9 who implied that they do not have any attachments to the platforms apart from using them just to gain income. When asked to describe their relationship to the platforms, seven SPs demonstrated a positive attitude towards the platforms. Case 2, in particular, identified with the platform by saying that "their problems are my problems". On the contrary, Cases 1 and 3 implied that they were indifferent about their respective platforms.

In terms of organizational citizenship behavior (OCB), two facets were investigated: organizational citizenship behavior towards the organization (OCBO) and organizational citizenship behavior towards the individual (OCBI). Six out of nine SPs demonstrated high OCBO while five out of nine demonstrated high OCBI. It is important to notice that OCB is low for Cases 8 and 9; this is because these SPs only deliver services once in a while since they do it only when traveling long distances. On the other hand, Cases 3 and 4 mentioned that their activities are done in a rush so that they have no time to interact, hence accounting for the low OCBI. Although findings regarding OCB differ among the participants, most participants demonstrated significant levels of trust that the platform reps care about and consider the SP interests.

When it comes to job satisfaction, all SPs seemed to be satisfied across the three defined dimensions: psychological meaningfulness, psychological safety, and psychological availability. Moreover, eight out of nine participants perceived a sense of personal development from their activities on the platforms; only Case 3 was of the opposite opinion. To fully understand the scope of satisfaction SPs derived from their activities on particular platforms, they were asked about their intentions to continue providing services on the same platform. Apart from Cases 3, 5 and 6 , the remaining participants demonstrated a will to continue providing services on the same platforms. The difference is because Cases 3, 5 and 6 are graduating college students, and hence they are looking for other employment options where they can develop career-wise. Nevertheless, they mentioned that after settling in other jobs, they would still be willing to provide service in the GE\&SE.

Lastly, the opinions of all participants demonstrated a common pattern of positive WOM. In fact, some SPs mentioned that they have already recommended their friends to join the platforms, mainly as service providers. Cases 1, 8, and 9 also recommended using their respective platforms to prospective customers. Although they speak positively of the platforms, however, they do not advocate for providing services on these platforms as a fulltime employment. Rather, they suggest that one does it as a side job. This finding was not surprising since almost all of the SPs have other jobs as their main occupation.

\subsection{Customer satisfaction}

Table 4 shows the results for customer satisfaction. Rating systems are commonly used in PBLM as a means for customers to give feedback to SPs after the delivery of a service. Thus, they can be used to reveal levels of customer satisfaction. Only half of the represented platforms have a transparent rating system that allows SPs to see customers' comments about their services, although SPs mentioned that they learn from this feedback on how to improve their services. Cases 8 and 9 operating in the carpooling sector revealed that a new policy was introduced recently that allows SPs to also rate customers to increase transparency. For Cases 5, 6 and 7 customer feedback is only seen by the platform reps; however, SPs are informed when customers give a negative review. Another remarkable point is that, even though some SPs do not directly receive the customers' reviews, they perceive that their customers are generally satisfied. Case 3 reported that they do not have a rating system; additionally, given that when delivering packages SPs scarcely have interactions with the customers, gauging the customer's satisfaction is hard. 
Table 4. Results for Customer Satisfaction

\begin{tabular}{lll}
\hline & \multicolumn{1}{c}{ Ratings } & \multicolumn{1}{c}{ Overall Satisfaction } \\
\hline Case 1 & The rating satisfies me. & $\begin{array}{l}\text { My customers are highly } \\
\text { satisfied and do come } \\
\text { back to my house. }\end{array}$ \\
\hline Case 2 & $\begin{array}{l}\text { I am happy with the } \\
\text { rating. }\end{array}$ & $\begin{array}{l}\text { My guests mostly want to } \\
\text { come back. }\end{array}$ \\
\hline Case 3 & N/A & Can't be measured. \\
\hline Case 4 & $\begin{array}{l}\text { I am happy with the } \\
\text { rating. }\end{array}$ & $\begin{array}{l}\text { The customers were } \\
\text { generally satisfied. }\end{array}$ \\
\hline Case 5 & $\begin{array}{l}\text { Only the platform has } \\
\text { access to customer } \\
\text { reviews. }\end{array}$ & $\begin{array}{l}\text { - Can't be measured. } \\
\text { - The customers were } \\
\text { generally satisfied. }\end{array}$ \\
\hline Case 6 & $\begin{array}{l}\text { Only the platform has } \\
\text { access to customer } \\
\text { reviews. }\end{array}$ & $\begin{array}{l}\text { - Can't be measured. } \\
\text { - The customers were } \\
\text { generally satisfied. }\end{array}$ \\
\hline Case 7 & $\begin{array}{l}\text { Only the platform has } \\
\text { access to customer } \\
\text { reviews. }\end{array}$ & $\begin{array}{l}\text { - N/A } \\
\text { - The customers were } \\
\text { generally satisfied. }\end{array}$ \\
\hline Case 8 & $\begin{array}{l}\text { The rating satisfies me. } \\
\text { Case 9 } 9\end{array}$ & $\begin{array}{l}\text { The customers were } \\
\text { generally satisfied. }\end{array}$ \\
\hline
\end{tabular}

\section{Discussion}

\subsection{Internal branding}

In general, the interview participants tended to confirm the existence of communication channels through which they address and are addressed by the platform reps regarding various concerns. This aligns with previous findings, which showed that dialogues between SPs and platform reps were common in SE [7]. Yet, surprisingly carpooling interviewees (Cases 8-9) were not aware of any communication channels they could use to communicate with the platform reps. Moreover, these participants were uncertain whether the platform takes into consideration the feedback provided by SPs. They mainly said so because they have not been asked for feedback yet. The uncertainty was also demonstrated by other participants (Cases 1, 4 and 7). This lack of awareness, however, does not directly imply the absence of communication channels through which feedback can be provided. Rather, it could indicate that this information is not clearly communicated before new SPs start operating on the platforms. Still, Cases 5 and 6 indicated that SP feedback is considered and confirmed it by sharing examples of cases when SPs suggested improvements in their services, and the platforms implemented them.

The response from Case 4 is interesting, as it seemed to be counterintuitive. They indicated that the platform collects weekly surveys from SPs, but the SP did not think the feedback is considered. One possible explanation is that the weekly surveys are more of a tool to help SPs reflect on the challenges they encountered during their weekly activities. This in return improves the quality of the SP's service, not necessarily because of new strategies implemented by the platform. It is rather because through the reflection SPs learn from each mistake and improve their services. Though they help SPs to improve, these surveys do not intend to collect SPs' feedback.

Brand knowledge is generally transferred to SPs through orientation seminars (either online or inperson), or through the terms and guidelines that are shared via generic emails. An interesting finding from this construct is that platforms that offered in-person orientation seminars and followed up with SPs by reminding them of the brand values and promises seemed to have SPs that feel as brand representatives. On the other hand, SPs who receive information only via generic emails and newsletters consider themselves as individual entities separate from the brand. However, they appear to fully understand the expectations attached to their roles as SPs, which they derive from the rules and guidelines.

A common observation among the latter category is that SPs do not read the generic emails. In fact, one SP commented, "I already unsubscribed from the newsletter. Maybe it might contain some brand-related information, but I did not find it informative". Other SPs mentioned that they do not read the regular emails sent through the platforms. Statements made by most of them were, "I only read the headline and maybe the first one or two lines but never read the email fully" and "I find it to be a waste of time". This is a rather unfortunate situation because brand knowledge dispatched from the platform will not be delivered, as intended, to the SPs. It could potentially result in incongruences between the brand values communicated to and expected by customers, and those they perceive from their encounters with SPs.

While four participants found platform representatives to be helpful in instances when SPs face difficulties that require support from the platform as an organization, the remaining 5 had a different perception. For Case 8 and Case 9, the reason behind the uncertainty is because they have not encountered an incident that required assistance from the representatives particularly. Both participants implied that the platform itself is well designed and user friendly; "most of the assistance you would need including the compensation of canceled rides are performed by the in-built algorithm" said Case 9. Case 3 and Case 4 described their platforms' assistance to be unhelpful because on occasions when they reached out for assistance, representatives were unreachable. 


\subsection{Service provider engagement}

Although all SPs joined their work on the platforms mainly motivated by the desire to earn money, the full engagement of fresh food delivery SPs (Cases 5-7) seems to be triggered by other factors more than just the money. This was demonstrated through their comments saying that although they could work long shifts, and even under bad weather sometimes, they would still feel refreshed and happy after their shifts as opposed to experiencing exhaustion and burnout [20]. Being students in a foreign country, these SPs derive enthusiasm from the opportunities offered by their work to meet different people, learn the local language quickly, get to know the city, and relieve the stress accumulated through schoolwork.

The same observation was made with participants from the hospitality sector (Cases 1-2); they also indicated the opportunity to meet people from different cultures as the main motive to provide their services, followed by the desire to make earnings from the activities. Case 1 felt fascinated by the services and commented by saying, "hosting people from different cultures gives me a perception that I have a piece of the whole world in my house". SPs from both the hospitality and FFD sectors admitted that their services identify with their personality, which explains why they derive high levels of satisfaction from their job. The participants also seem to possess higher levels of OCB as compared to other SPs.

As observed from the results, however, other participants also appear to be satisfied with their job and share values with the platforms to some extent. Even those who are not committed to the organization and do not demonstrate OCB still possess positive WOM, intend to stay on the platforms for as long as they can, and demonstrate trust in the platform as an organization. Apart from Case 8, who identified the environmental sustainability aspect of the GE as the main driver to their participation in the Carpooling sector, other SPs in the PD and Carpooling sector mentioned that earning money was their only motive.

Unsurprisingly, they do not demonstrate any OCB. Even though Case 3 said, "I try all possible means to find the customer", the main reason is not to represent the brand, rather it is to economize fuel costs. When probed further, the SP reported, "when I deliver packages, the customer will only get to see me and my car. They will not associate my service with any brand since I have nothing representing the brand". Participants from the FFD (Cases 5-7) on the other hand, associate their services with the brand and demonstrate high levels of OCB both towards the organization (OCBO) and towards the individual (OCBI). Although it may appear to be counterintuitive, the fact that SPs have different expectations and aspirations before starting to provide their services may explain why all participants find their participation in the GE\&SE to be meaningful.

By evaluating results for service provider engagement, it can be noticed that all participants had fairly similar opinions on most of the constructs. However, results for constructs such as organizational commitment and OCB appear to present significant differences among the responses. Based on this observation, it can be inferred that FFD SPs stand out to demonstrate higher levels of engagement as compared to other SPs.

\subsection{Customer satisfaction}

When it comes to the customer satisfaction aspects, it was an interesting observation that platforms that seem to be implementing internal branding practices at a higher degree compared to the whole sample are the ones that do not allow SPs to directly view the customers' feedback on their service delivery. According to the participants, when customers give negative feedback, the representatives evaluate it and communicate the issue to all SPs. This could be a good approach as it facilitates SPs to learn from fellow SPs' mistakes; hence, the occurrence of the same mistake is prevented. However, it is good for SPs to also see good feedback from customers, since it provides them with morale and pride in their services [20].

Still, SPs in the fresh food delivery sector reported that they could assess the satisfaction levels of the customer via Smalltalk conversations they had with customers upon delivery. They also implied that the customer's satisfaction would be proportional to the gratuity - also known as 'tip', they give [21]. Further, the SPs mentioned that through their services, they have established friendships with their customers. Given that these bonds derive from perceived quality service, there is a possibility that customers will also have positive WOM and attract more customers.

Overall, all interviewed SPs perceived that their customers were generally satisfied (case 3 could not assess). This homogeneity of answers prevents us from deriving conclusions on the relation between internal branding and customer satisfaction.

\subsection{Recommendations}

\section{SP Engagement and Disengagement}

From some incidents shared by the participant SPs, it was identified that SPs can experience either engagement or disengagement depending on the type of environment they operate in. Highly engaged SPs will always be dedicated to considering what is best 
for the customer and the organization, whereas disengaged SPs, might tend to quit the organization. Moreover, as engagement is a dynamic concept [13], SPs can easily switch from one state to the other. For instance, Case 1 explicitly shared an incident in which the individual requested assistance from the platform's representatives concerning a review that cost the individual's benefits of a privileged SP. Although the review was controversial, and despite all efforts invested by the SP, the perceived assistance was not fair, and the SP felt mistreated. "I was really frustrated and wanted to quit this platform", said Case 1. Although the SP stayed on the platform, as a result of the incident, the SP's organizational trust has reduced, "I do not expect much from them" said the SP. Also, their relationship to the platform is indifferent even though they share some values with the platform.

This shows how the perceived support from the platform reps might yield into either engagement or disengagement of SPs. Thus, platform reps should be careful when dealing with SPs because perceived unfair treatment can result in SPs performing poorly or even switching to other platforms that would offer them better promises. Thus, poor performance would result in low customer satisfaction and loyalty, whereas high SP turnover would result in high costs of $\mathrm{SP}$ attraction and retention and weak brand reputation.

\section{Knowledge dissemination}

Additionally, the study has revealed that SPs who received in-person orientation and are reminded of the brand values and promises from time to time, through internal branding practices, generally tend to have a sense of attachment to the platform. They perceive themselves to be brand representatives when they are performing their duties. This approach is, however, not practical when it comes to bigger platforms that have several SPs in different areas around the globe. Gathering all SPs in one location might be relatively not possible but transferring information to SPs via generic emails and newsletters does not present a viable solution either. Platform representatives should look for ways of disseminating their crucial brand knowledge interactively and concisely to ensure that all SPs consider it. The message could be communicated through short interactive videos or graphic content that can be viewed from the platform apps or websites instead of long generic emails.

\section{Organizational citizenship behavior}

The analysis of the results has revealed that SPs from the FFD area tend to be more engaged than SPs from other areas. Besides, they also seem to demonstrate higher OCB that purely derives from their identification with their job. Thus, they dedicate more effort towards fulfilling the expectations of the customer in the name of the brand (OCBO). The fact that they do even have private chat groups through which SPs coordinate get-togethers explains why they exhibit high levels of OCBI. On the contrary, SPs from the carpooling and PD areas demonstrated the lowest OCB, which can be explained by their relationship with the platform - "I do it to earn money. No other attachments". Given that all these SPs operate under the same labor market conditions, the factor highlighted in the results that could account for the observed differences in behavior is internal branding. It appears that SPs who have experienced internal brand communications will tend to be more engaged in their work than their counterpart.

There is a high chance that these SPs who are only motivated by earnings would easily switch to another platform that gives them more earnings. However, those who possess higher OCB will be more likely to exhibit discretionary efforts when on their duties, and they will tend to stay with the platform for longer since they have a sense of attachment to their activities on the platforms deriving from the SPs' values and beliefs. Further, participants implied the usability of the platform to be of high importance. To perform their role, SPs need to connect and constantly stay in contact with the customer. Thus, SPs find the usability of platforms (in terms of mobile apps or websites) to be essential. Hence, firms should invest in building welldesigned and user-friendly interfaces in order to facilitate the activities of SPs.

Research in the field of marketing has revealed that firms can influence consumer behaviors by conducting strategic branding activities in their target market [22]. In the context of the GE\&SE, although they are mostly perceived as partners, SPs are also customers of the platforms in principle, and without them, platforms would not be able to conduct business. Therefore, it can be deduced that platforms could potentially influence the attitudes and behaviors of SPs by strategically devising internal brand communications.

\section{Conclusion}

This study aimed to investigate whether platforms operating in the GE\&SE perform internal branding activities as a means to transfer brand knowledge to SPs and whether these activities do affect the SPs' perceptions towards their platforms. The results have shown how strategically oriented internal branding practices can play a key role in enhancing the SP engagement levels with an aim to achieve high-quality service. The findings of the study suggest that highly engaged service providers will go the extra mile to satisfy the customers' needs. Moreover, they possess 
positive WOM and have intentions to stay longer with the platform. Thus, high SP engagement levels, good quality service and high customer satisfaction will lead to higher organizational benefits.

According to the authors' knowledge, this research presents an alternative approach of measuring and enhancing customer satisfaction in GE\&SE. Thus, one of the main limitations of this study involved applying metrics normally used to measure employee engagement in traditional market settings to GE\&SE. The second main limitation stems from the interviewee sample size. The nine interviewed SPs represented only six different platforms. Although the market sectors of the selected platforms are diverse, the sample size is relatively small to represent the totality of platforms operating in the GE\&SE. In particular, more cases with low customer satisfaction need to be explored in order to derive a generalizable conclusion on the relation between internal branding and customer satisfaction in the GE\&SE.

This paper serves as a foundation for further research on the topics of internal branding and employee engagement in GE\&SE. Although our results show evidence that internal branding practices can potentially enhance engagement levels of service providers, further studies can focus on evaluating the appropriate metrics to assess the antecedents of service providers' engagement. Besides, this research explores the GE\&SE from a service-based perspective. Further research can consider a larger and varied sample by including professional freelancers in order to account for the knowledge-based segment of service providers. This will allow for a full representation of the GE\&SE.

As many firms enter the GE\&SE competition, more chances are created for workers to switch from one platform to another one offering better working conditions. This, on the other hand, is a disadvantage for the platforms since the cost of retaining SPs is increasing with more competition in the market. Thus, firms are obliged to develop sustainable strategies for attracting and retaining SPs. By implementing internal branding practices that help SPs to identify with the platform personally, there is a higher chance of reducing the SP turnover rate. Further, firms can invest in learning the factors that affect the engagement of the SPs in order to enhance SPs' engagement by devising internal branding strategies systematically.

Finally, SPs who demonstrate high levels of engagement tend to exhibit discretionary efforts when providing their services. In addition, they possess positive word-of-mouth and have intentions to stay longer with the platform. All these benefits together point towards high customer satisfaction levels, which is the ultimate goal of all firms in the service sector, and especially in the GE\&SE.

\section{References}

[1] S. J. Barnes and J. Mattsson, "Understanding collaborative consumption: Test of a theoretical model," Technol. Forecast. Soc. Change, vol. 118, pp. 281-292, 2017.

[2] M. R. Gleim, C. M. Johnson, and S. J. Lawson, "Sharers and sellers: A multi-group examination of gig economy workers' perceptions," J. Bus. Res., vol. 98, no. June 2018, pp. 142-152, 2019.

[3] J. Frazer, "How The Gig Economy Is Reshaping Careers For The Next Generation," 2019. [Online]. Available: https://www.forbes.com/sites/johnfrazer1/2019/02/15/how-thegig-economy-is-reshaping-careers-for-the-nextgeneration/\#3f9ff3749ada. [Accessed: 14-Jul-2020].

[4] H. Johnston, C. Land-Kazlauskas, and others, "Organizing ondemand: Representation, voice, and collective bargaining in the gig economy," Cond. Work Employ. Ser., vol. 94, 2018.

[5] A. J. Ravenelle, "Sharing economy workers: selling, not sharing," Cambridge J. Reg. Econ. Soc., vol. 10, no. 2, pp. 281-295, 2017.

[6] A. Andjelic, "Luxury brands are failing in their storytelling | Media Network | The Guardian," 2015. [Online]. Available: https://www.theguardian.com/medianetwork/2015/nov/23/luxury-brands-marketing-failingstorytelling. [Accessed: 14-Jul-2020].

[7] D. Volkova, "Internal Branding in the Sharing Economy: the Key to Customer Satisfaction," Jacobs University Bremen, Germany, 2019.

[8] A. Punjaisri, K., Wilson, "The role of internal branding in the delivery of employee brand promise," Brand Manag., vol. 15, no. 1, pp. 57-70, Sep. 2007.

[9] R. Whisman, "Internal branding: a university's most valuable intangible asset," J. Prod. Brand Manag., vol. 18, no. 5, pp. 367370, Aug. 2009.

[10] S. Shibata, "Gig work and the discourse of autonomy: Fictitious freedom in Japan's digital economy," New Polit. Econ., vol. 25, no. 4, pp. 535-551, 2020.

[11] M. Volkin, "Why The Gig Economy Will Drive The Future Of Employment," 2020. [Online]. Available: https://www.forbes.com/sites/forbescoachescouncil/2020/03/27/w hy-the-gig-economy-will-drive-the-future-ofemployment/\#31cb6b7f4f52. [Accessed: 14-Jul-2020].

[12] M. B. Shuck, T. S. Rocco, and C. A. Albornoz, "Exploring employee engagement from the employee perspective: Implications for HRD,” J. Eur. Ind. Train., 2011.

[13] W. A. Kahn, "Psychological conditions of personal engagement and disengagement at work," Acad. Manag. J., vol. 33, no. 4, pp. 692-724, 1990.

[14] C. King and D. Grace, "Building and measuring employee-based brand equity," Eur. J. Mark., vol. 44, no. 7/8, pp. 938-971, Jul. 2010.

[15] A. M. Saks, "Antecedents and consequences of employee engagement," J. Manag. Psychol., 2006.

[16] W. H. Macey and B. Schneider, "The meaning of employee engagement," Ind. Organ. Psychol., vol. 1, no. 1, pp. 3-30, 2008.

[17] K. L. Barriball and A. While, "Collecting data using a semistructured interview: a discussion paper," J. Adv. NursingInstitutional Subscr., vol. 19, no. 2, pp. 328-335, 1994.

[18] H. J. Rubin and I. S. Rubin, Qualitative Interviewing: The Art of Hearing Data, 2nd ed. Thousand Oaks, CA: Sage Publications, 2005 .

[19] S. Khan and R. VanWynsberghe, "Cultivating the under-mined: Cross-case analysis as knowledge mobilization," in Forum qualitative Sozialforschung/forum: Qualitative social research, 2008, vol. 9, no. 1.

[20] C. Maslach, W. B. Schaufeli, and M. P. Leiter, "Job burnout," Annu. Rev. Psychol., vol. 52, no. 1, pp. 397-422, 2001.

[21] C. Becker, G. T. Bradley, and K. Zantow, "The underlying dimensions of tipping behavior: An exploration, confirmation, and predictive model," Int. J. Hosp. Manag., vol. 31, no. 1, pp. 247256, 2012.

[22] D. I. Hawkins and D. L. Mothersbaugh, Consumer behavior: Building marketing strategy. Boston: McGraw-Hill Irwin, 2010. 